\title{
Note on the diet of the jaguar in central Brazil
}

\author{
Rahel Sollmann • Julie Betsch • \\ Mariana Malzoni Furtado • Heribert Hofer • \\ Anah T. A. Jácomo • Francisco Palomares • \\ Severine Roques • Natália Mundim Tôrres • \\ Carly Vynne • Leandro Silveira
}

Received: 21 November 2012 /Revised: 26 February 2013 /Accepted: 28 February 2013 /Published online: 14 March 2013

(C) Springer-Verlag Berlin Heidelberg 2013

\begin{abstract}
Diet of the jaguar Panthera onca in the Cerrado, central Brazil, was investigated based on a sample of genetically identified jaguar scats. At least nine prey species were observed in 35 scat samples. Giant anteaters Myrmecophaga tridactyla contributed more than $75 \%$ of biomass to the observed diet. Tapirs Tapirus terrestris and peccaries Tayassu pecari and Pecari tajacu contributed approximately $6 \%$ to jaguar diet each, and small mammals contributed least to the jaguar diet. At 0.121 , dietary niche breadth was narrower than reported in most other studies. Due to their physical characteristics and abundance, giant anteaters are likely the most profitable prey for jaguars in Emas National Park, and as an important prey, they should be included in jaguar conservation efforts.
\end{abstract}

Communicated by C. Gortázar

R. Sollmann · M. M. Furtado · A. T. A. Jácomo • N. M. Tôrres •

L. Silveira

Jaguar Conservation Fund/Instituto Onça-Pintada, Mineiros,

Brazil

R. Sollmann $\cdot$ H. Hofer

Leibniz Institute for Zoo and Wildlife Research, Berlin, Germany

J. Betsch

College of Forestry and Conservation, University of Montana,

Missoula, MT, USA

M. M. Furtado

Universidade de São Paulo, Faculdade de Medicina Veterinária e

Zootecnia, São Paulo, Brazil

F. Palomares $\cdot$ S. Roques

Department of Conservation Biology, Estación Biológica de

Doñana (CSIC), Sevilla, Spain
Keywords Cerrado $\cdot$ Giant anteater $\cdot$ Myrmecophaga tridactyla $\cdot$ Panthera onca $\cdot$ Peccaries $\cdot$ Tapirs $\cdot$ Tapirus terrestris

\section{Introduction}

Many carnivore species are of conservation concern due to habitat conversion and conflict with humans. Depletion of a carnivore's prey base can reduce its population size and lead to local extinction (Karanth and Chellam 2009). Thus, understanding dietary requirements of carnivores is a prerequisite for their conservation.

The jaguar Panthera onca (Linnaeus, 1758) is the largest cat of the American continent. With more than 80

\section{N. M. Tôrres}

Departamento de Biologia Geral, Universidade Federal de Goiás, Goiânia, Brazil

C. Vynne

Department of Biology, University of Washington, 24 Kincaid Hall,

Seattle, WA, USA

R. Sollmann $(\bowtie)$

Department of Forestry and Environmental Resources, North Carolina State University, Campus Box 7646, Raleigh, NC 276958003, USA

e-mail: rsollma@ncsu.edu 
documented prey species (Seymour 1989), jaguars are opportunistic predators that feed preferably on medium to large prey species (Lopez-González and Miller 2002; Oliveira 2002). The jaguar is classified as 'near threatened' owing to decreasing population trends (IUCN 2011). Its range has reduced by approximately $45 \%$ over the last century (Zeller 2007). Here, we investigate jaguar diet in the Cerrado grasslands of central Brazil, where the species remains little studied and is classified as endangered (Moraes Jr. 2012).

\section{Material and methods}

The Cerrado covers $21 \%$ of Brazil; over the last 35 years, more than half has been transformed into cultivated land (Klink and Machado 2005). Emas National Park (ENP) is located in south-western Goiás $\left(18^{\circ} 19^{\prime} \mathrm{S}, 52^{\circ} 45^{\prime} \mathrm{W}\right)$, in a highly productive agricultural region. Its $1,320 \mathrm{~km}^{2}$ protect large tracts of grassland plains with patches of shrub fields, marshes and riparian forest. During the wet season (October to March), rainfall averages $1,500 \mathrm{~mm}$. There is very little precipitation during the rest of the year.

We quantified jaguar diet based on 39 genetically identified jaguar scats collected with the aid of scat detector dogs (14 collected by the Jaguar Conservation Fund-JCF-in 2009 (Sollmann 2011) and analysed as described in Roques et al. (2011); 25 collected and analysed as described in Vynne et al. (2011, 2012) between 2004 and 2008) along $3,500 \mathrm{~km}$ of transects in ENP. Because yearly sample sizes were too small for separate analysis, we pooled samples across years. Genetic fingerprinting showed that samples belonged to at least 12 individuals (CV and JCF, unpublished data).

We identified non-digested prey remains to the lowest possible taxonomic level using a reference collection (Quadros 2002). For each prey species $i$, we counted the frequency of occurrence in the scats $f_{i}$; when a scat sample contained remains of more than one species, these were counted as fractional contributions to the frequency of the respective species (Link and Karanth 1994). We calculated relative scat frequency $f r_{i}$ as

$f r_{i}=f_{i} / \sum f$.

To estimate the contribution of biomass of each species, we applied the method by Wachter et al. (2012) who, based on feeding trials with cheetahs, established a regression formula to calculate biomass consumed per field collectable scat, $y$, as a function of live weight of prey species, $x$, taking into account that this relationship is not linear:

$y=2.358 \times(1-\exp (-0.075 x))$.
Table 1 Prey species identified in 35 jaguar scats from Emas National Park, central Brazil

\begin{tabular}{llllll}
\hline Species & $f$ & fr & MPW $(\mathrm{kg})$ & BPS $(\mathrm{kg})$ & $b$ \\
\hline Tapir & 2.00 & 0.06 & 239 & 2.36 & 0.08 \\
Peccary & 2.00 & 0.06 & 24.5 & 1.98 & 0.07 \\
Giant anteater & 26.17 & 0.74 & 30.5 & 2.12 & 0.76 \\
Agouti & 1.17 & 0.03 & 2.9 & 0.46 & 0.01 \\
Opossum & 0.33 & 0.01 & 1.25 & 0.21 & $<0.01$ \\
Domestic cattle & 1.00 & 0.03 & 175 & - & 0.05 \\
Capybara & 0.50 & 0.01 & 50 & 2.30 & 0.03 \\
Unidentified felid $^{\mathrm{a}}$ & 1.33 & 0.04 & - & - & - \\
Unidentified bird/reptile $^{\mathrm{a}}$ & 0.50 & 0.01 & - & - & - \\
\hline
\end{tabular}

$f$ absolute scat frequency, $f r$ relative scat frequency, $M P W$ mean prey weight according to unpublished data by the Jaguar Conservation Fund (unpublished data) and Reis et al. (2006), BPS biomass consumed per field collectable scat, following Wachter et al. (2012), $b$ relative biomass consumed

${ }^{\mathrm{a}}$ Not considered in calculations involving biomass because body weight could not be determined

We calculated relative biomass consumed $b_{i}$ as

$b_{i}=f r_{i} y_{i} / \sum f r \times y$.

We obtained body weight of prey species from field data from ENP (JCF, unpublished data) and Reis et al. (2006). To estimate dietary niche breadth, we calculated Levins' index B (Levins 1968):

$B=1 / \sum b^{2}$.

We standardized $B$ according to Hurlbert (1978):

$B_{\mathrm{A}}=(B-1) /(I-1)$,

where $I$ is the total number of species in the diet. We performed all calculations in the free software $\mathrm{R}$ version 2.13.0 (R Development Core Team 2011).

\section{Results}

Four scats did not contain identifiable prey remains. In the remaining 35 scats, giant anteater Myrmecophaga tridactyla was the dominant prey species, contributing $76 \%$ to the consumed biomass. We also found remains of tapir (Tapirus terrestris), capybara (Hydrochaeris hydrochaeris), opossum (Didelphis albiventris), domestic cattle (Bos taurus), peccaries (Tayassu pecari or Pecari tajacu), agouti (Dasyprocta sp.) and unidentified birds/reptiles and felids (Table 1). Since the felid and bird/reptile remains could not be identified to genus 
level, these were excluded from further analyses. Standardized niche breadth was 0.121 .

\section{Discussion}

Although the results from our small data set collected across several years and seasons need to be interpreted with care, with over $75 \%$ of consumed biomass giant anteaters seemed the most important prey species of jaguars in ENP. Though large $(30 \mathrm{~kg})$, these solitary foragers are well below a jaguar's own body weight and thus unlikely to inflict serious injury, which is one of the main foraging costs for large predators (Berger-Tal et al. 2009). As jaguar population density in ENP is as low as $0.3-0.6$ individuals $/ 100 \mathrm{~km}^{2}$ (Sollmann et al. 2011) and there are 20 to 40 giant anteaters per $100 \mathrm{~km}^{2}$ (Miranda et al. 2006), they may be sufficiently abundant to become the stock prey of the jaguar.

A strong preference of the giant anteater by the jaguar has not been observed before. In general, jaguar dietary niches are broader than the 0.121 observed in the present study (Leite and Galvão 2002; Núñez et al. 2002; Scognamillo et al. 2003; Azevedo and Murray 2007; Azevedo 2008). Only Foster et al. (2009) observed a similarly narrow niche in undisturbed forests in Belize, where armadillos made the largest contribution to jaguar diet. However, the small sample size in the present study (Foster et al. 2010) and the fact that we excluded unidentified species from niche breadth analysis may have contributed to the narrow niche we observed.

Both tapirs and peccaries made relatively low contributions (6-7\% of consumed biomass) to the jaguar diet in ENP. Most studies report tapirs as an infrequently taken prey (Novack et al. 2005), which may be a consequence of tapirs being larger than the jaguar. In contrast, peccaries are often cited as important prey (Polisar et al. 2003; Azevedo and Murray 2007; Cavalcanti and Gese 2010). The low frequency of occurrence in scats could be a function of the overall small sample size. Alternatively, jaguars may prey less intensely on the group-living peccaries in ENP because of the abundance of the more vulnerable giant anteater. Small mammals (agoutis and opossums) played a secondary role in jaguar diet in ENP, which is expected for this large predator (Lopez-González and Miller 2002).

Giant anteaters have undergone a steady population decline in the region of ENP over the last decades (Collevatti et al. 2007); peccaries are frequently killed in the park's surroundings in retaliation to crop raiding (Jácomo 2004). Since the conservation of large felids depends on the conservation of their prey, these and other prey species should be included in future jaguar research and conservation efforts in ENP.
Acknowledgments This study received financial support from the Disney Worldwide Conservation Fund, Fundação Monsanto, the Earthwatch Institute, the Memphis Zoo, the Leibniz Institute for Zoo and Wildlife Research, the Fundación BBVA (project BIOCON 05 100/06) and Idea Wild. RS received a scholarship from the German Academic Exchange Service (DAAD). We thank ICMBio for granting permission to work in ENP and ENP management for logistical support. We thank the kennels Canil Caraíbas and HR for their technical support regarding the scat detector dogs. We are indebted to the entire Jaguar Conservation Fund team, all Earthwatch volunteers and interns, and especially Raphael Almeida, Tiago Boscarato and Grasiela Porfírio for the help with field work and scat analysis. We thank Mirjam Nadjafzadeh for comments on the manuscript.

\section{References}

Azevedo FC (2008) Food habits and livestock depredation of sympatric jaguars and pumas in the Iguacu National Park area, south Brazil. Biotropica 40:494-500

Azevedo FC, Murray DL (2007) Spatial organization and food habits of jaguars (Panthera onca) in a floodplain forest. Biol Conserv 137:391-402

Berger-Tal O, Mukherjee S, Kotler B, Brown J (2009) Look before you leap: is risk of injury a foraging cost? Behav Ecol Sociobiol 63:1821-1827

Cavalcanti S, Gese EM (2010) Kill rates and predation patterns of jaguars (Panthera onca) in the southern Pantanal, Brazil. J Mammal 91:722-736

Collevatti RG, Leite KC, Miranda GH, Rodrigues FH (2007) Evidence of high inbreeding in a population of the endangered giant anteater, Myrmecophaga tridactyla (Myrmecophagidae), from Emas National Park, Brazil. Genet Mol Biol 30:112-120

Foster RJ, Harmsen BJ, Valdes B, Pomilla C, Doncaster CP (2009) Food habits of sympatric jaguars and pumas across a gradient of human disturbance. J Zoology 280:309-318

Foster RJ, Harmsen BJ, Doncaster CP (2010) Sample-size effects on diet analysis from scats of jaguars and pumas. Mammalia 74:317321

Hurlbert SH (1978) The measurement of niche overlap and some relatives. Ecology 59:67-77

IUCN (2011) IUCN red list of threatened species. Version 2011.2. $<$ www.iucnredlist.org $>$. Accessed 14 Dec 2011

Jácomo AT (2004) Ecologia, manejo e conservação do queixada (Tayassu pecari) no Parque Nacional das Emas e em propriedades rurais do seu entorno. Ph.D. thesis, Universidade de Brasília, Brasília, Brazil

Karanth KU, Chellam R (2009) Carnivore conservation at the crossroads. Oryx 43:1-2

Klink CA, Machado RB (2005) Conservation of the Brazilian Cerrado. Conserv Biol 19:707-713

Leite MR, Galvão F (2002) El jaguar, el puma y el hombre en tres áreas protegidas del Bosque Atlantico costero de Paraná, Brasil. In: Medellín RA, Equihua C, Chetkiewicz CL, Crawshaw PG Jr, Rabinowitz AR, Redford KH, Robinson JG, Sanderson EW, Taber A (eds) El jaguar en el nuevo milenio, Ediciones Científicas Universitárias. Universidad Nacional Autónoma de Mexico/Wildlife Conservation Society, New York, pp 237-250

Levins R (1968) Evolution in changing environments: some theoretical explorations. Princeton University Press, Princeton

Link WA, Karanth KU (1994) Correcting for overdispersion in tests of prey selectivity. Ecology 75:2456-2459 
Lopez-González CA, Miller BJ (2002) Do jaguars (Panthera onca) depend on large prey? West N Am Naturalist 62:218-222

Miranda GHB, Tomas WM,B. Valladares-Padua CB, Rodrigues FHG (2006) Giant anteater population survey in Emas National Park, Brazil: a proposed monitoring program. Endangered Species UPDATE 23:96-103

Moraes EA Jr (2012) The status of the jaguar in the Cerrado. Cat News Special Issue 7:25-28

Novack AJ, Main MB, Sunquist ME, Labisky RF (2005) Foraging ecology of jaguar (Panthera onca) and puma (Puma concolor) in hunted and non-hunted sites within the Maya Biosphere Reserve, Guatemala. J Zoology 267:167-178

Núñez R, Miller B, Lindzey F (2002) Ecología del jaguar en la reserva de la biosfera Chamela-Cuixmala, Jalisco, México. In: Medellín RA, Equihua C, Chetkiewicz CL, Crawshaw PG Jr, Rabinowitz AR, Redford KH, Robinson JG, Sanderson EW, Taber A (eds) El jaguar en el nuevo milenio, Ediciones Científicas Universitárias. Universidad Nacional Autónoma de Mexico/Wildlife Conservation Society, New York, pp 107-126

Oliveira TG (2002) Comparative feeding ecology of the jaguar and puma in the Neotropics. In: Medellín RA, Equihua C, Chetkiewicz CL, Crawshaw PG Jr, Rabinowitz AR, Redford KH, Robinson JG, Sanderson EW, Taber A (eds) El jaguar en el nuevo milenio, Ediciones Científicas Universitárias. Universidad Nacional Autónoma de Mexico/Wildlife Conservation Society, New York, pp 265-288

Polisar J, Maxit I, Scognamillo D, Farrell L, Sunquist ME, Eisenberg JF (2003) Jaguars, pumas, their prey base, and cattle ranching: ecological interpretations of a management problem. Biol Conserv 109:297-310

Quadros J (2002) Identificação microscópica de pelos de mamíferos brasileiros e sua aplicação no estudo da dieta de carnívoros. M.S. thesis, Universidade Federal do Paraná, Curitiba, Brasil
R Development Core Team (2011) R: a language and environment for statistical computing. R Foundation for Statistical Computing, Vienna

Reis NR, Peracchi AL, Pedro WA, Lima IP (eds) (2006) Mamíferos do Brasil. Londrina, Brazil

Roques S, Adrados B, Chavez C, Keller C, Magnusson W, Palomares F, Godoy J (2011) Identification of Neotropical felid faeces using RCP-PCR. Mol Ecol Resour 11:171-175

Scognamillo D, Maxit IE, Sunquist M, Polisar J (2003) Coexistence of jaguar (Panthera onca) and puma (Puma concolor) in a mosaic landscape in the Venezuelan llanos. J Zoology 259:269-279

Seymour KL (1989) Panthera onca. Mammalian species 340:1-9

Sollmann R (2011) Ecology and conservation of the jaguar (Panthera onca) in the Cerrado grasslands of central Brazil. Ph.D. thesis, Freie Universität Berlin, Berlin, Germany

Sollmann R, Furtado MM, Gardner B, Hofer H, Jacomo AT, Tôrres NM, Silveira L (2011) Improving density estimates for elusive carnivores: accounting for sex-specific detection and movements using spatial capture-recapture models for jaguars in central Brazil. Biol Conserv 144:1017-1024

Vynne C, Keim JL, Machado RB, Marinho-Filho J, Silveira L, Groom MJ, Wasser SK (2011) Resource selection and its implications for wide-ranging mammals of the Brazilian Cerrado. PLoS One 6: e28939

Vynne C, Baker MR, Breuer ZK, Wasser SK (2012) Factors influencing degradation of DNA and hormones in maned wolf scat. Anim Conserv 15:184-194

Wachter B, Blanc A-S, Melzheimer J, Hoener OP, Jago M, Hofer H (2012) An advanced method to assess the diet of free-ranging large carnivores based on scats. PLoS One 7(6):e38066

Zeller K (2007) Jaguars in the new millennium data set update: the state of the jaguar in 2006. Wildlife Conservation Society, New York 